MERGERS AND

THE CLAYTON ACT 



\section{MERGERS AND \\ THE CLAYTON ACT}

\section{By DAVID DALE MARTIN}

UNIVERSITY OF CALIFORNIA PRESS

Berkeley and Los Angeles · 1959 
UNIVERSITY OF CALIFORNIA PRESS

BERKELEY AND LOS ANGELES, CALIFORNIA

CAMBRIDGE UNIVERSITY PRESS, LONDON, ENGLAND

(C) BY THE REGENTS OF THE UNIVERSITY OF CALIFORNIA LIBRARY OF CONGRESS CATALOG CARD NUMBER: 59-13085

PRINTED IN THE UNITED STATES OF AMERICA

DESIGNED BY HARRY MARKS 